Federico Fellini: from catholicism to the collective unconscious

Mäder, Marie-Therese

Posted at the Zurich Open Repository and Archive, University of Zurich ZORA URL: https://doi.org/10.5167/uzh-129171

Book Section

Published Version

Originally published at:

Mäder, Marie-Therese (2016). Federico Fellini: from catholicism to the collective unconscious. In: Burnette-Bletsch, Rhonda. The Bible in motion : a handbook of the Bible and its reception in film. Berlin/Boston: De Gruyter, 635-648. 


\section{Federico Fellini: From Catholicism to the Collective Unconscious}

The interface between Federico Fellini's (1920 - 1993) oeuvre and religion is rich but complex and evident in a broad range of religiously connoted topics, motifs, stories, and styles. Literal biblical references rarely appear in Fellini's cinematic universe. Nevertheless they are present, often visualized and materialized in a subverted character. For biblical reception in Fellini's work is mediated through his interpretation of Catholic ideas inasmuch as he received the biblical tradition in a thoroughly Roman Catholic context.

Fellini's creative period, which started in 1950 with Luci del varietà (a.k.a.Variety Lights) and ended in 1990 with La voce della luna (a.k.a. The Voice of the Moon), comprises twenty-four films that he directed. Films without reference to Roman Catholicism are in the minority, as Fellini unremittingly accused the Church and its agents of factitiousness and ambivalence. Roman Catholic censors officially banned La tentazione del dottor Antonio (1962, a.k.a. The Temptation of Dr. Antonio, a contribution to the omnibus production Boccaccio '70) and 81/2 (1963). Conservative groups protested at the screenings of other works. Fellini's critical ambivalence toward the Church is repeatedly evident in the aesthetic of his work and attests to the significance of Roman Catholicism in his familial, social, and educational background. Fellini has explained Roman Catholicism's inescapable presence in his life story:

It's difficult biologically and geographically not to be a Catholic in Italy. It's like a creature born beneath the sea - how can it not be a fish? For one born in Italy, it's difficult not to breathe, from childhood onward, this catholic atmosphere. One who comes from Italian parents passes a childhood in Italy, enters the church as baby, makes his Communion, witnesses Catholic funerals - how can he not be a Catholic? Still, I have a great admiration for those who declare themselves a detached laity - but I don’t see how this can happen in Italy. (Cardullo 2006, 40-41)

Fellini's experience of being raised in the Roman Catholic tradition provided him with a large pool of symbolic, ethical, and ritual material on which to draw. This material was later supplemented through his interest in supernatural experiences, such as medium-led séances, and in the Jungian theory of dreams, archetypes, and the unconscious. As a result, a vast spectrum of religious symbols, themes, and dimensions populate Fellini's films, derived not only from Roman Catholicism but also from spiritual, supernatural, and psychoanalytical ideas.

The Italian director was born on January 20, 1920, as the first child of a Roman Catholic middle class family in Rimini, Italy. His filmography is closely related to and an important part of his personal interests and their development. This chapter therefore follows the chronology of Fellini's films, with a specific focus on individual 
scenes. On that score the analysis concentrates on three particular references in his work: (1) to the Roman Catholic Church, and especially to its agents, ethical issues, institutional aspects, and power relations, (2) to miracles, especially in their substance and form within a Roman Catholic context (Stubbs 2006, 1-36), and (3) to dreams, phantasies, and archetypes as understood by psychoanalyst Carl Gustav Jung (Stubbs 2006, 37-69; Bondanella 1992, 150 -226).

\section{Suffering, Repentance and Mercy in the Humanitarian Fifties}

While working as a scriptwriter and assistant director in the 1940s, Fellini had been embedded in the tradition of Italian neorealism, but he subsequently, and quickly, found his own artistic style. On an ethical level, Christian understandings of issues such as suffering, guilt, forgiveness, repentance, and redemption play a crucial role in Fellini's seven black and white productions of the 1950s. In all these productions, a certain ambivalence toward the Roman Catholic Church is expressed. Some protagonists experience relief, but that amelioration never lasts for long as in Lo sceicco bianco (1952, a.k.a. The White Sheikh). In this first film as sole director we encounter the Fellini universe at its best.

Lo sceicco bianco contains two storylines, each driven by one of the protagonists. In the first, a young married couple, Wanda and Ivan Cavalli, travel to Rome for the first time. Ivan wants to introduce his young wife to his relatives in order to impress his uncle, an employee at the Vatican. The uncle arranges for the young couple to attend an audience with the pope. The second storyline tells of Wanda's secretly meeting the hero of a soap opera called the "White Sheikh." As soon as she has a chance, she sneaks away from the hotel room to go to the soap opera's production office. Meanwhile Ivan is looking for Wanda in the streets of Rome, encounters two prostitutes (Cabiria is played by Giulietta Masina), and spends the night with one of them. In the morning the hospital calls Ivan to tell him that his wife had tried to kill herself but that he can take her home. With less than one hour until the audience at the Vatican, time is running out. Ivan meets Wanda at the hospital. Both are crying and both repent their actions, although they do not recount the full stories to each other. They arrive on time at St. Peter's Square, to be welcomed by Ivan's relatives, who had been told by Ivan that Wanda was unwell and are happy to see her recovered. As the couple proceeds hand in hand to their audience with the pope, the bells of St. Peter's ring out. They have forgiven each other, without knowing the details of each adventure. Wanda looks at her husband and tells him, "Ivan, mio sceicco bianco sei tu!" (You are now my White Sheik!). ${ }^{1}$

1 All translations of Italian dialogue are by the author. 
The happy ending does not see the innocence of the couple restored, but through the institution of the church, they can return to a conventionalized reality. The audience alone knows both storylines and can detect the ambiguous overtones. The image of the innocent couple is to be preserved without digging more deeply. Fellini portrayed how he believed institutional religion functioned. The church watches over morals, but its concerns are superficial. The truth can be suppressed to allow the church to frame the perfect Roman Catholic couple.

Two worlds depicted in Lo sceicco bianco are typical of Fellini's narratives. On one hand, we encounter a self-reflexive attitude toward artistic work, its milieu, and its agents. In Lo sceicco bianco that setting is provided by the soap opera; elsewhere in Fellini's work it is provided by the circus (La strada, 1954; I clowns, 1970), theatre and variety shows (Luci del varietà, 1950), film (Intervista, 1987), television (Ginger e Fred, 1986), and an orchestra (Prova di orchestre, 1979). The artist is often a morally ambivalent and sad outsider; the behavior of some artists is unstable, exaggerated, and excessive (Stubbs 2006, 105-107). On the other hand, we are provided with a depiction of Christian morality that represents a second world, but one that is just as ambivalent as the artist's world. The attitudes of the Roman Catholic Church provide a double moral standard, for the church sets up its values and norms in opposition to the artistic lifestyle, which its agents denounce as undignified. Watching over morality and proper conduct, the adherents of the institutional church seek to regulate everyday life and to control fantasy - but without success in either field. The pressures applied by Christian morality and values also play a crucial role in I vitelloni. The idea of marriage as a promise kept for life is also found in other Fellini films from this period, but with a less hopeful outcome as in Agenzia matrimoniale. $^{2}$

The plot from Fellini's early years as director is conciliatory, leading up to a happy ending, but by contrast, the protagonists are not saved in the black-andwhite narration of later productions. Fellini encourages no compassion for either offender or victim. The poor, naïve, and helpless figures are mostly exposed to evil while they still believe in miracles. The suffering of the characters reinforces the emotionality of the story and stimulates the empathy of the audience.

Ethically these films focus on values based on Christian concepts of charity, which is, in turn, closely connected to suffering, repentance, and redemption (Wiegand 2003, 42-71). For example, in La strada (1954, "The Road") the amiable tramp Gelsomina (Giulietta Masina) is delivered up to the arbitrary brutality of Zampanò (Anthony Quinn). Only when he learns of her death does he recognize the error of his ways, as now he misses her. To a certain extent Gelsomina could be considered as Christ-figure and the whole film as a Christian parable. In Il bidone (1955, "The Swindle") three swindlers dress up as clergymen and recount invented stories to

2 The film is part of the omnibus production Amore in città (1953), with short films directed by Michelangelo Antonioni, Alberto Lattuada, Dino Risi, and Cesare Zavattini among others. 
poor and credulous peasants in order to acquire their money. After one fellow wants out of the business, his companions attack him with stones and take all his money, leaving him gravely injured and alone in the wasteland, where he dies.

Aesthetically these narrations are full of Roman Catholic symbols employed in emotional situations and often at turning points: Touched by a large procession that includes crosses and statues, Gelsomina kneels down as it passes by her. Later, during her journey with Zampanò, she meets a warm and loving nun in a cloister, where the travelers can stay overnight. Gelsomina feels accepted and comfortable in this place and cries when they have to leave in the morning. Picasso in Il bidone sees a statue of the Virgin Mary and starts to regret having lied to his wife; after hearing church bells ring out, he decides to go home. In Le notti di Cabiria (1957, a.k.a. Nights of Cabiria) friends invite the prostitute Cabiria to join them on a pilgrimage to a shrine to the Virgin Mary. The place is crowded with praying and chanting people full of hope and expectation. Votive offerings are brought, candles are sold, and a procession tries to reach the church. Cabiria queues to see the picture of the Virgin Mary, praying for help to change her life. After the ritual she desperately realizes that nothing has changed. The sad ending is anticipated, even as Cabiria hopes for a better future.

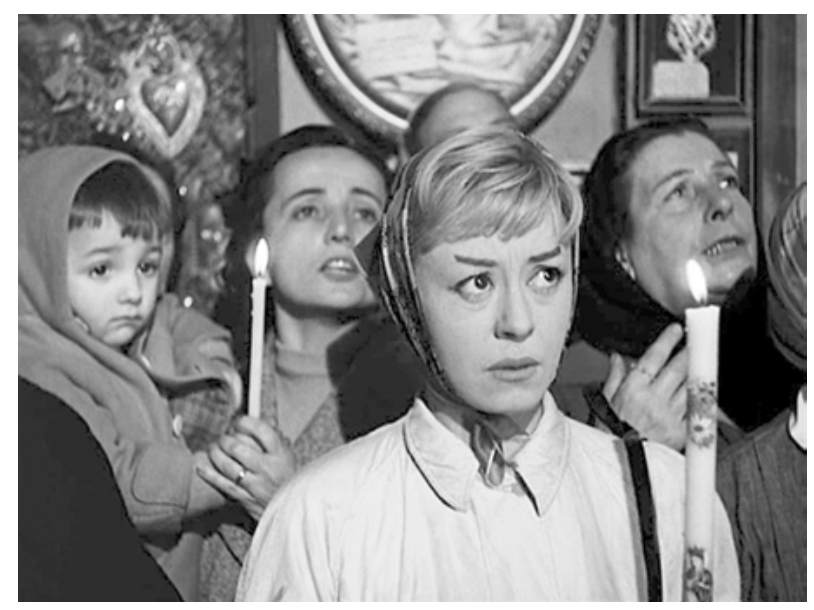

Fig. 73: Praying for a miracle in Le notti di Cabiria (1957)

Fellini's roots as a filmmaker lay in Italian neorealism, traces of which can be determined in his portrayal of ordinary people - Wanda and Ivan, Sandra and Fausto, Picasso, Augusto, or the outsider figures Gelsomina and Zampanò - as well in his shooting on location and his use of lay actors. But at the same time Fellini was developing his own artistic style, which has been termed by Chris Wiegand a "phantastical individualism" (Wiegand 2003, 43). Fellini's striking success in the 1950s, evident in the Academy Awards for Best Foreign Film awarded to La strada and Le notti die Cabiria, would only continue to grow. 


\section{Death and Transience in the Self-Reflexive 1960s}

As the film studio grew in significance in the 1960s, Fellini was able to develop his fantastical story worlds. Roman Catholic symbolism can still be found in La dolce vita, La tentazione del dottor Antonio, and 81/2, but criticism of Roman Catholicism is now more pronounced. And while Catholicism is still visible in the setting, it no longer has either impact on individuals or effect on society. Increasingly religious tradition is portrayed as an empty shell. As in the opening scene of La dolce vita (1960, "The Sweet Life"), which criticizes the materiality and superficiality of the Roman Catholic Church. On May 1, 1957, a huge statue of Jesus had been transported by helicopter to St. Peters Square. That event is recalled in La dolce vita when this singular combination is seen flying over the roofs of the outskirts of Rome. The bells of St. Peter's are ringing so loudly that the noise of the helicopter is drowned out. The statue of Jesus and the paparazzi Marcello (the term "paparazzi" was invented by this film), the protagonist, are introduced together. Marcello Rubini (Marcello Mastroianni) is an aspiring writer in search of novelties amongst the Roman upper class.

The latter and the arrival of the statue of Jesus at the Vatican are staged as spectacles for the mass media, but so too are religious rituals. The miraculous appearance of the Virgin Mary to some children is transformed into a sensational television event, with paparazzi everywhere. In the midst of the exaggerated excitement about the possible miracle, a sick girl, who had been brought to the site by her mother in hope that she would be healed, dies. The morning after the "false" miracle the visitors and even the paparazzi, still shocked by the incident, listen in silence to the priest's Latin benediction of the death. This scene portrays a rare and brief moment in La dolce vita, in which a religious professional creates a silent and respectful atmosphere.

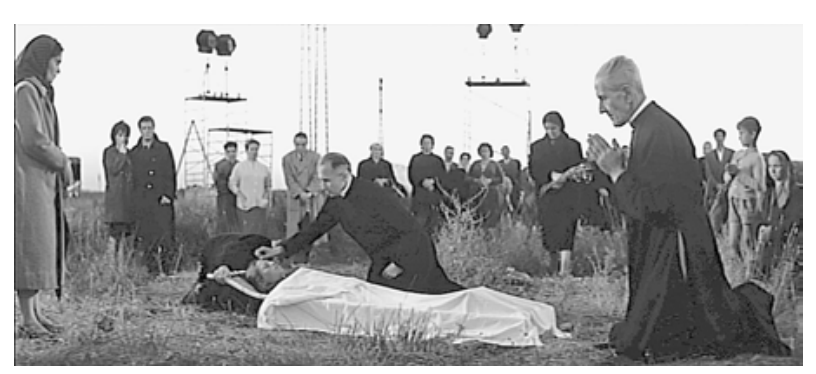

Fig. 74: A mother seeks a miracle for her sick daughter in La dolce vita (1960)

In La tentazione del dottor Antonio (1962, The Temptation of Dr. Antonio) the double moral standards of Christian politicians are again criticized. In the film the politician Dr. Antonio is distracted by a large and tempting advertisement that has been placed in front of his house. On this poster, a woman, Anita Ekberg, seductively promotes the drinking of milk. The film introduced the topic of temptation and uncontrolled 
dreams, to which Fellini returned in a number of subsequent productions. The director was very interested in Jung's dream theory, although at the time references to the Roman Catholic Church were still plentiful. He connected these two worldviews, the Roman Catholic and the Jungian, in $81 / 2$, which proved highly successful and provided noteworthy insight into the mind of a film director.

The opening sequence of $81 / 2$ (1963) considers the uncontrolled unconscious as it portrays a nightmare experienced by the middle-aged film director Guido Anselmi (Marcello Mastroianni). Unable to escape his creative crisis, Anselmi cannot finish his film. At the end of the film, during a meeting with journalists, he hides under a table and shoots himself. The narration ends as it had begun, with a dream sequence in which the director finishes his film. The film portrays its subject's self-seeking attempt to form a continuous narrative of his life. Anselmi, Fellini's alter ego, is omnipresent as the first-person narrator. The protagonist is searching for authenticity and individual truth within a context shaped by religious tradition and public opinion (Pamerleau 2009). Several scenes reference Roman Catholicism as a defining element of the principal protagonist's daily life and biography. In his process of selfdiscovery, the morality on which religious tradition and the church insist is a demanding obstacle that needs to be overcome.

This issue can be seen clearly in the scene in which Anselmi asks for the advice of a clergyman, as a representative of the Church, about his screenplay, which will deal with religious issues. The clergyman insists that some topics, such as religion, cannot be broached by cinema because films often mix the sacred with profane love. Subsequently the director is introduced to another clergyman, this time a cardinal, who does not even listen to the director's doubts.

The feeling of not being heard by representatives of the Church is recapitulated in a flashback. Anselmi recalls being caught, along with his friends, watching the prostitute Saraghina dance on the beach. A humiliating punishment had followed, in front of his teachers, all of them clerics, and in the presence of his cruel-hearted mother. Having confessed and repented, the boy returns to Saraghina. The punishment could not stop him watching the prostitute's dance.

In a subsequent dream sequence, Anselmi again encounters the cardinal, this time in the steam bath. At the end of their conversation the cardinal stresses that there is no salvation outside the Church and states that if you don't belong to the "civitas dei" you belong to the "civitas diabolic." The door to the bishop's bath is closed, symbolically also closing off the path to the Church.

In addition to many other prizes, $81 / 2$ was awarded Fellini's third Oscar in the category Best Foreign Film; simultaneously the film was banned by the Roman Catholic Church. Fellini was now at the zenith of his achievement as a director. His public and personal falling out with the Church portrayed in $8^{1 / 2}$ was not picked up again in subsequent productions. 


\section{Dreams and LSD in the Supernatural Mid-Sixties}

Fellini's interest in Jungian psychology and paranormal phenomena strongly influenced his later works. John Stubbs has identified possible connections between Fellini's engagements with religious belief and with Jungian psychology, arguing that "Jung provided Fellini with a kind of equivalent belief system that could supplant more traditional religious belief: in short, an ordering vision, if not a philosophy" (Stubbs 2006, 260). Although Fellini has forcibly rounded on those who have understood Jungian theory as a belief system, recording, "I am terribly impatient with people who dismiss Jung as a nutcase who took himself for an Aryan Christ," (Pettigrew $2003,83)$ Jungian archetypes that include the concept of the anima and animus and the collective conscious can be understood as forming parallels with a religious worldview (Morgenthaler 2002, 234-246).

Fellini's experimentation with psychedelic drugs also provided multifaceted sources of inspiration. In the mid-1960s he had started to experiment with LSD under the supervision of psychoanalyst, parapsychologist, and journalist Emilio Servado, one of the founders of Italian psychoanalysis. This new preoccupation left conspicuous traces in his films with the fact that all his films were now shot in color. Fellini's colorful aesthetic, which Frank Burke has termed "one of the most vivid explorations of color in the history of the medium," (Burke 1996, 137) formed a significant stylistic means of expressing the supernatural and unconscious realm.

In Giulietta degli spiriti (1965, a.k.a. Juliet of the Spirits), which mirrors Fellini's interest in paranormal phenomena, visual differences between dreams, reality, the subconscious, and the supernatural are difficult to discern. Betrayed by her husband, Giulietta is searching for the true spiritual experience. She does not believe that séances can provide access to the spirit world, but she holds that she herself encounters that world through the voices she hears. The narration is full of religious symbols and rituals that are Roman Catholic, supernatural, or psychological: the martyr play, the séances with the medium, the guru meeting, and the psychodrama, for example. But none of these encounters can help Giulietta in her lonely situation as betrayed wife. With a last gaze into the lens of the camera, she withdraws into her personal imagination where, Burke writes, "her mind and world are conjoined" (Burke 2003, 137). Giulietta's transformation comes from her leaving this world behind and envisaging a new beginning.

Toby Dammit in Tre passi nel delirio (a.k.a. Spirits of the Dead), Fellini's third contribution to an omnibus production also deals with the world of spirits. The film is based on a short story by Edgar Allen Poe in which an English Shakespearean actor, named Toby Dammit, receives an Italian award. His prize takes the form of a yellow Ferrari, which Dammit drives when very drunk, resulting in his death. Toby Dammit is full of critical and even satiric references to Christianity and Roman Catholicism, set in the context of show business. Dammit's award, for example, is given in recognition of his role as Jesus in an Italian Western. In a television interview, in response to the journalist's question whether the devil looks like a black 
cat, a bat, or a ghost, Dammit answers: "O no, I am English, not Catholic! To me the devil is cheerful. He looks like a little girl.” The actor's imagination shows the devil as a girl dressed in white playing with a white ball, very much the opposite of the conventional religious typology recalled by the journalist in the interview. Not only in this answer but also in the unfolding of the story, Dammit starts to free himself of the limitations of his life as an actor. Finally the devil frees him from this demanding system during his fateful drive: Dammit is beheaded by a bar as he tries to run over the white-dressed girl with the white ball.

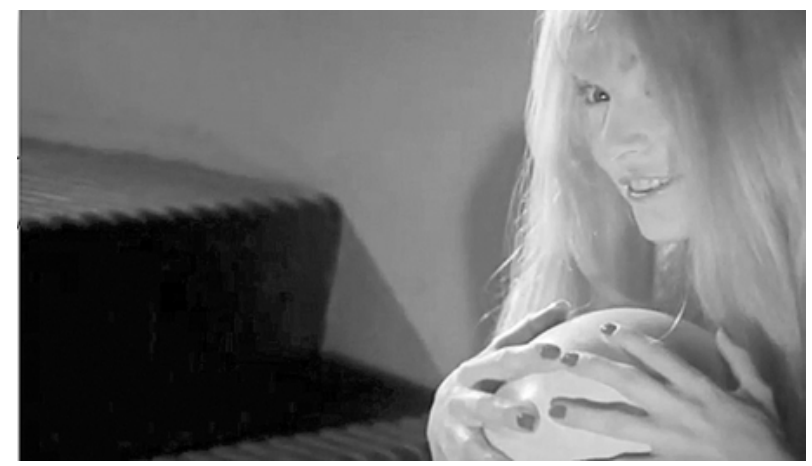

Fig. 75: The devil in Toby Dammit (1968)

Again show business and religion, both institutional and social, are intermingled, with each depicted as a false, superficial, and exploitative system. The successful actor who voluntarily follows the devil can be read as a religious worldview conquering the film industry. The colorful tint in red and orange acts as a surreal reminder of the haze of a nightmare or the fire of purgatory. The film's style is a reference to an aesthetic of the 1960s in which drug experiences and engagement with the unconscious were central. The power and attractiveness of the metaphysical, paired with the surreal and fantastical style of excess, shape the colorful Felliniesque universe.

Fellini Satyricon (1969), Fellini's first historical film, provides an excessive narration of Roman antiquity. For a while Fellini leaves Roman Catholicism behind and turns his attention to another Italian cultural myth, which he deconstructs in a discontinuous narrative as a fantasy of the past. The film is based on text fragments of the Roman poet Petronius. The travelogue through an unknown past is full of references to the collective unconscious and archetypes of Jung. The two protagonists, Encolpio and his pupil Ascilto, a homosexual couple, provide continuity in the fragmented narration. The film is a metaphor for the nature of history and its contingent process. Fellini scrutinizes Roman decadence, highlighting perverted behavior. Death, marriage, and sacrificial rituals are excessively staged, with the participants driven by sexual and material instincts. Remarkably, the tagline of the U.S. film poster was "Rome before Christ. After Fellini." Even though it was an inaccurate 
description as the narration is situated in the first century A. D., the wording is adequate according to the unique representation of antiquity in film history.

\section{Coming of Age and the End of Life in the 1970s and Early 1980s}

In Roma and Amarcord Fellini returned to biographically inspired topics. Both films are coming-of-age stories centered on young male adult(s) discovering life in a specific social setting. The tensions between reality, on one hand, and fantasies or dreams, on the other, and between the present and memories are interwoven with multifaceted and unsparing references to Roman Catholicism and to the fascist Italy of Fellini's youth. The power of fascism to suppress, supported by religious agents, and the connections of both fascism and Roman Catholicism to the myths of Roman antiquity formed another defining moment in Fellini's work.

The interface of Roman Catholicism, the militarism of fascism, and Roman myth is displayed in the beginning of Roma (1972, a.k.a. Fellini's Roma). In a Roman Catholic boys' school, a class is watching a slide-show presentation by their teacher, a priest, about important sites in Rome. One slide, secretly inserted, shows a (almost) naked woman from the back, sitting astride a chair. The pupils scream enthusiastically when they see the forbidden image. In a panic, the teacher orders that the projector be turned off, and shouts repeatedly: "Close your eyes! It's the devil! Don't look!" The supervisor, his stick in hand, intones "Inno a Roma” (hymn to Rome) by Giacomo Puccini, a piece of music heard often and on diverse occasions in fascist Italy. After a transition to black, a family is seen sitting at the table in their dining room. The maid enters, screaming excitedly that the pope is on the radio. The father tries to stop his family from kneeling down and praying but he loses the fight against the clout of the Vatican. The fascist regime is dominant in the public sphere, but in the private sphere the religious institution still reigns. The young Fellini, as a boy in the countryside and as young adult in Rome, is perfectly able to cope with both regimes. Fellini, as director of Roma and in real life, draws on his memories as an endless source of fantasy to show how fascism and Roman Catholicism complemented each other.

Amarcord (1973) tells another nostalgic coming-of-age story, looking back this time to Fellini's place of birth, Rimini, in the 1930s. The film shows fascism starting to take control in the provincial town on the Adriatic coast while the Roman Catholic Church continues to oversee morals. Sexuality and youthful desire provide the motors of the narrative. The actions and presence of fascist agents are starting to influence public life. But neither church nor political party has complete control. In short scenes, the sexual experiences of five friends are depicted, with a voiceover by one of the boys. What the boys recount in their confessions and what really happened are not the same. The boys handle the double moral standards of the Church skillfully. 
Indeed, it seems that clerical supervision promotes sexual desire instead of preventing it.

This confession sequence is followed by a parade of fascists. The camera tracks the running participants, who tell of their commitment to the new fascist Roman Empire and honor the "Federale," the leader of the district. The sequential editing of the boys' confessions and the fascist parade holds up individual and group rituals to ridicule. The participants themselves do not question the fact of the confession or the parade; they simply adapt outwardly as is necessary. Fellini reveals the emptiness and insignificance of such rituals in the mise-en-scène and the editing. By setting the sexual desire of male youth against the church and the political party, he undermines both authorities. Neither system is able to control (sexual) life and fantasies.

Roma and Amarcord have a sentimental undertone strongly connected to Fellini's youth in Rimini and his fledgling years in Rome. Further productions in the 1970s and 1980s consider male midlife crisis and aging. The idea of decay is connected to the protagonists' increasing estrangement from the present, a topic Fellini had already addressed earlier, in his middle phase, in I clowns, which depicted clowns as a species that was dying out. Il casanova di Fellini (1976, Fellini's Casanova) and La città delle donne (1980, City of Women) also focus on male protagonists as they seek to come to terms with social changes and their male identity. E la nave va (1984, And the Ship Sails On), a film in a film, directs its focus at a decadent society gathering on a ship. None of these films use explicit religious references as Fellini's earlier works had done, but they do consider the meaning of life. Analysis of a sequence in $\mathrm{Il} \mathrm{Ca}$ sanova di Fellini makes evident their implicit religious-philosophical perspective and Fellini's continuing distinct references to Jung.

Il casanova di Fellini is about an aging womanizer who is losing his ability to attract and seduce women. John Stubbs interprets the film in light of the Jungian concept of anima, which refers to the female within the man (Stubbs 2006, 57):

The job of the anima may be to show what is knowable in the unconscious, but it is also to show us there is more. This 'more' is what I have called the 'ineffable' earlier, and it is perhaps the most important aspect of Jung's appeal for Fellini. It is not necessary to group or understand the ineffable. By definition, that is impossible. But what is important is to know that it exists. The mediatrix can offer such assurances. (Stubbs 2006, 62-63)

"Mediatrix" is a term used in Mariology in reference to Mary in her role as mediator between Jesus Christ and mankind (McBrien 2005, 7884). The religious dimension of the "ineffable" is evident in its reference to a transcendental realm beyond the representational. According to Jung, the concept of anima is connected universally to the male existence. Images of the anima appear in dreams in the form of archetypes derived from the collective unconscious. As already noted, Fellini used Jung's symbol system as a rich fundus for interpretation of the psychic condition of his male protagonists in crisis.

In one scene Casanova (Donald Sutherland) passes through the whale's mouth into its belly. The whale symbolizes the vagina, in which Casanova is meeting with 
the collective unconscious. ${ }^{3}$ The whale motif may also be connected, however, with the narrative of the disobedient Jonah in the Old Testament. The showman at the funfair praises the whale: "The great Mouna! The king of the whales. The Leviathan of Jonah. Everybody may enter. The belly is still warm." Inside the belly a slide show displays outsized sketches of the female sex with, for example, a small man lying on a women's labs, and the vagina with a corona of snakes or in the form of a spiral sucking in small male figures or as a frightening face. The whale's belly is frightening connoting sexual fantasies. Likewise, Marcello Snaporaz (Marcello Mastroianni), the male protagonist in La città delle donne, is searching for his anima on a journey to the unconscious, but without success. This time the protagonist is not able to find the mediatrix of his anima. The narration may express Fellini's difficulties in dealing with the changing contemporary world, as well as with his role as a male in the wake of the social revolution of 1968, and a clear dissociation of feminism, which was difficult to integrate into his male-centered universe (Burke 2003, 320-36).

In both films, Fellini mingles Christian symbols with Jung's archetypes in an expressive setting composed of sexual dream phantasies. The strategy of connecting these two belief systems results in a personal religious worldview typical of Fellini's late phase. The unconscious is turned into a transcendental power induced by sexual desire and expressed in archetypes.

\section{The End: Looking for Real Miracles in the 1980s}

Fellini's late works Ginger e Fred (1986) and Intervista (1987, a.k.a. Interview) express an obvious discomfort with television. Fellini questions the new and successful system of signification located outside the religious or psychological realm, and his final films often, according to Burke, "not only exemplify but dispute postmodernity, especially the relative 'meaningless' that endless signification seems to imply" (Burke 1996, 24).

The meaninglessness of mass media is portrayed in Ginger e Fred, when an old and formerly successful dance couple (Giulietta Masina and Marcello Mastroianni) reunite to perform in a Christmas show. The director of the show is looking for "wonders" that might touch the audience, like having a clergyman who fell in love present his beloved during the show or a woman is hearing voices from beyond. Ginger and Fred's intent is, however, somewhat different: they want to perform their dance number despite a number of possible hurdles - forgetting the steps and the constraints of their age, for example - as a means of recalling their good times. Their achievement is not a miracle that is evidence of a power "somewhere out there," but neither is their dance simply for the television show. Their performance, an authentic, satisfying, and live experience, is exclusively for themselves.

3 The whale is called Mouna, which, according to John Baxter is a term for "vagina" in the Romagnola dialect; see Stubbs (2006, 63). 
In a similar vein, by recalling former times in Intervista Fellini makes evident that miracles take place only in film studios. The film director, again played by Fellini himself, as in Roma and I Clowns, recounts to a Japanese journalist and her team of film reporters a dream about filmmaking that is self-evidently set in Cinecittà, the largest film studio in Italy and where many of Fellini's films were shot. Fellini meets again his screen gods, Marcello Mastroianni and Anita Ekberg - "The first women of the creation!", as Mastroianni had called her in La dolce vita. At the end, after a rainstorm, the members of the film crew receive a panettone, a typical Italian cake, and wish each other "Merry Christmas!" as they leave the set. Christian rituals now belong simply to everyday life, providing a shared point of orientation and a group identity marker.

Perhaps as Fellini lost his faith in contemporary society, he felt increasingly secure in his memories of the past. With La voce della luna ${ }^{4}$ (1990, a.k.a. The Voice of the Moon) Fellini takes leave of the world. Two lunatics, Ivo Salvini and Nestore Gonnello, are confused by and alienated from the behaviors and events of contemporary civilization, such as discotheques, beauty competitions, and the Japanese tourists who whisk around a small Italian village. At the end Salvini, alone in a field, addresses the moon: "Probably [Or else] I think that there was a little more silence, if everybody was a little silent, maybe we'd be able to understand something." By sticking his head into the well from which he had emerged at the beginning of the story, he withdraws forever to his own universe.

Fellini died on October 31, 1993, in Rome. His body lay in state in studio number 5 in Cinecittà, wearing the evening dress that he had worn to the Oscar ceremony at which he had received the Lifetime Achievement Award (Kezich 2005, 589-615). Many representatives of the Roman Catholic Church were present at his funeral, to honor the great director. Probably Pier Paolo Pasolini (1986/87) is right with the following comment: "What counts in Fellini is that which endures eternally and absolutely in his broadly Catholic ideology, his loving and sympathetic optimism" (Pasolini 1986/87, 198). Fellini was born as a Roman Catholic, and he was buried as a Roman Catholic. The circle is complete.

This short overview demonstrates how the Italian director's religious education and biographical background basically filtered and formed biblical references in his oeuvre. On one hand, his films subvert traditional interpretations, conventions, and norms of the biblical narrative. On the other hand, they likewise augment the narrative with Felliniesque motifs. But the distinctive aesthetic still remains within Catholic realm, as it conveys a certain affection and fascination for material, visual, and sensual realization of the Christian worldview. Fellini's excessive portrayal of religious dimensions exposes and repeatedly penetrates the Church's institutional power and its agents.

4 La voce della luna is loosely based on the novel Il Poema dei Lunatici by Ermanno Cavazzoni; see Burke (1996, 290). 


\section{Works Cited}

Bondanella, Peter. 1992. The Cinema of Federico Fellini. Princeton, N.J.: Princeton University Press. Burke, Frank. 1996. Fellini's Films. From Postwar to Postmodern. New York: Twayne.

Burke, Frank, and Marguerite R. Waller, eds. 2002. Federico Fellini: Contemporary Perspectives. Toronto: University of Toronto Press.

Cardullo, Bert, ed. 2006. Federico Fellini: Interviews. Jackson, Miss.: University Press of Mississippi.

Kezich, Tullio. 2005. Federico Fellini. Eine Biographie. Transl. Sylvia Höfer. Zürich: Diogenes.

McBrien, Richard. 2005. "Roman Catholicism." In Encyclopedia of Religion. Ed. Lindsay Jones. 2nd ed. Vol. 12. Detroit: Macmillan. Pp. 7884.

Morgenthaler, Christoph. 2002. "Carl Gustav Jung (1875-1961)." In Klassiker der

Religionswissenschaft. Von Friedrich Schleiermacher bis Mircea Eliade. Ed. A. Michaels. 2nd ed. Munich: C. H. Beck. Pp. 234-46.

Pamerleau, W. C. 2009. Existentialist Cinema. New York: Palgrave Macmillan.

Pasolini, Pier Paolo. 1986/87. "The Catholic Irrationalism of Fellini." Film Criticism 11.2: 190-200. Pettigrew, Damain, ed. 2003. I'm a Born Liar: A Fellini Lexicon. New York: Harry N. Abrams.

Stubbs, John C. 2006. Fellini as an Auteur: Seven Aspects of His Films. Carbondale: Southern Illinois University Press.

Wiegand, Chris. 2003. Federico Fellini: The Complete Films. Cologne: Taschen.

\section{Films Cited}

$81 / 2$ (dir. Federico Fellini, 1963, Cineriz, IT/FR).

Amarcord [“I Remember"] (dir. Federico Fellini, 1973, F.C. Produzioni, IT/FR).

Amore in città ["Love in the City" omnibus project; Un agenzia matrimoniale; "Marriage Agency"]

(dir. Federico Fellini, 1953, Faro Film, IT).

Block-notes di un regista [a.k.a. A Director's Notebook] (dir. Federico Fellini, 1969, NBC, IT).

Boccaccio 70 [omnibus project; La tentazione del dottor Antonio, a.k.a. The Temptation of Dr.

Antonio] (dir. Federico Fellini, 1962, Cieriz, IT/FR).

E la nave va [a.k.a. And the Ship Sails On] (dir. Federico Fellini, 1984, Rai 1, IT/FR).

I clowns [a.k.a. The Clowns] (dir. Federico Fellini, 1970, RAI Radiotelevisione Italiana, IT/FR/DE).

Il bidone [“The Swindle"] (dir. Federico Fellini, 1955, Titanus, IT/FR).

Il casanova di Fellini [a.k.a. Fellini's Casanova] (dir. Federico Fellini, 1976, Produzioni Europee

Associati, IT/US).

Fellini's Satyricon (dir. Federico Fellini, 1969, Produzioni Europee Associati, IT).

Ginger e Fred [a.k.a. Ginger and Fred] (dir. Federico Fellini, 1986, Produzioni Europee Associati, IT/FR/DE).

Giulietta degli spiriti [a.k.a. Juliet of the Spirits] (dir. Federico Fellini, 1965, Rizzoli Film, IT/FR). I vitelloni [a.k.a. The Young and the Passionate] (dir. Federico Fellini, 1953, Cité Films, IT/FR). Intervista [a.k.a. Interview] (dir. Federico Fellini, 1987, Aljosha, IT).

La città delle donne [a.k.a. City of Women] (dir. Federico Fellini, 1980, Gaumont, IT/FR).

La dolce vita ["The Sweet Life"] (dir. Federico Fellini, 1960, Riama Film, IT/FR).

La strada ["The Road"] (dir. Federico Fellini, 1954, Ponti-De Laurentiis, IT).

La voce della luna [a.k.a. The Voice of the Moon] (dir. Federico Fellini, 1990, Cecchi Gori Group

Tiger, IT/FR).

Le notte di Cabiria [a.k.a. Nights of Cabiria] (dir. Federico Fellini, 1957, Dino de Laurentiis, IT/FR). 
Lo sceicco bianco [a.k.a. The White Sheikh] (dir. Federico Fellini, 1952, OFI, IT).

Luci del varietà [a.k.a. Variety Lights] (dir. Federico Fellini, 1950, Capitolium, IT).

Prova di orchestre [a.k.a. Orchestra Rehearsal] (dir. Federico Fellini, 1979, Daimo Cinematografica, IT/DE).

Roma [a.k.a. Fellini's Roma] (dir. Federico Fellini, 1972, Ulta Film, IT/FR).

Tre Passi nel delirio [a.k.a. Spirits of the Dead, omnibus project; Toby Dammit] (dir. Federico Fellini, 1968, Les Films Marceau, FR/IT). 